\title{
IMPACT OF THE COVID-19 PANDEMIC ON EDUCATION AND TRAINING
}

\author{
Anamaria BURADA, \\ PhD. Student, Doctoral School of Humanitas Sciences- "Ovidius" University of \\ Constanta, Romania, \\ E-mail: anamaria_burada@yahoo.com
}

\begin{abstract}
This article aims at presenting how the Covid-19 pandemic affected all areas of education in 2020, at all types and levels, from early to adult education as well as the reaction of European countries and institutions through the adopted educational policies. Education and training contribute decisively to the well-being and personal and professional development of citizens as well as to the resilience of the society and of the economy, having an important role in the recovery of societies.
\end{abstract}

Keywords: Covid-19; education; educational policies; pandemic;

\section{INTRODUCTION}

In the context of the Covid-19 virus pandemic, forcing schools around the world to move to virtual classrooms has raised the issue of the sustainability of this process among education experts, who are trying to build the future of online education for years to come. During this period of 2020, March-December, major changes took place in terms of the way we teach, communicate, learn, collaborate in the education and training process, with a major impact on all students, teachers, trainers, all types and all levels of education and training, from early education to adult education.

The term school as presented in this paper refers to all types of formal and non-formal educational institutions, at all levels of education, training, vocational, retraining institutions, non-formal education centres, adult education centres. The reopening of schools refers to the physical space for students and teachers in the schools that reopen as well as the entire educational process as it is known, prior to the period marked by the Covid-19 pandemic.

\section{ONLINE, REMOTE AND BLENDED LEARNING}

Online education is considered to be of lower quality than face-to-face education, despite research proving exactly the opposite. This rush to move so many institutions online has come with the perception that online education is a compromise situation, marked by low performance as well as by a much lower than expected efficiency.

However, a distinction must be made between e-learning and remote learning (Malcolm Brown, manager of the e-learning initiative education).

Malcolm Brown points out the difference between online learning and remote learning in the article "From emergency remote teaching to rigorous online learning", the first being planned and organized, while the second refers mainly to the use of technology in order to perform tasks designed for teaching in class. Remote teaching in emergency situations or 
remote learning refers to the sudden transition from learning in a classroom, physical spaces to learning in virtual classes, with specific functionalities and organizations.

Remote learning it is defined as the education offered to remote students without the usual face-to-face contact with a teacher in the classroom, with the support of television and online materials and programmes.

Online learning it is considered the education that takes place on the internet, part of remote learning programmes and can complete the teaching carried out in the classroom.

Blended learning combines face-to-face teaching and learning with the use of educational technology applications and students' interactions with online learning, helping them to achieve their learning goals.

Remote learning is compared to any other form of teleworking. The activity that normally takes place in real time is moved online, using applications and online collaboration platforms such as Cisco Webex, Zoom, Microsoft Teams, Google Meet for synchronous meetings and Google Classroom, Drive for teaching asynchronous materials. On the other hand, online learning involves much more planning. For a complete online university course, planning, development lasts from six to nine months (EDUCASE report).

It is interesting to note that online education is perceived as a telework activity for teachers rather than for direct beneficiaries, respectively pupils or students. This aspect can also be understood as a result of the fact that the standardised and organized work activity is specific to adults, unlike minors whose main formative activity is education.

Also, Kelvin Thompson, executive manager of the Centre for Distributed Learning, which has been offering online courses for 24 years, claims that $85 \%$ of students choose at least one online course, which is why a lot is invested in their infrastructure.

\section{INTERNATIONAL AND NATIONAL EDUCATIONAL POLICIES}

In the UNICEF Publication "Creating resilient education systems in the context of the Covid-19 pandemic. Considerations for local and school establishment decision makers" is argued that the resilience of education systems diminishes the impact of the pandemic on learning in the context of school closures. However, this has aggravated existing social inequities.

Schools are not only a place for academic education but also for learning social and emotional skills, for social interaction, challenging teachers, principals and those in charge with the education system and decision makers, local authorities or education administrations, ministries, national agencies and other relevant stakeholders in education, to find solutions for quality inclusive education. Thus, schools represent micro-social climates, with clear dimensions in which those present participate as exponents of the values they find in the family and also exercise various social roles and statuses, in a process of formation and transformation of personality. All the more so, the didactic staff, whether they are teachers or principals, managers of school organizations, counsellors and psychologists, have a particularly important impact in guiding the younger generations in terms of their development but also in the formation of their personality.

In Romania, although the National Education Law mentioned since 2011 in Chapter IV- Pre-university education curriculum and Chapter VII- Management of the system and educational establishments, Section 1, General provisions, articles 70, 94, para. 2 and letter t, the establishment of the Virtual School Library and of the School e-learning Platform, which include examples of lessons for the school curriculum topics, examples of assessment tests, 
guides, digital resources, protected by Copyright and related rights law 8/1996, as subsequently amended and supplemented, these becoming resources permanently accessible and free to any student or teacher, as well as the role of the Ministry of Education in building and ensuring their operation, the 2020 pandemic led to the forced digitalization of education.

Educational institutions and training institutions have made efforts to maintain the right to education. They currently use alternative options for remote learning and learning, various school learning platforms such as G-Suite with Google classroom and Google Meet, for synchronous and asynchronous teaching, Adservio, Microsoft Teams, Webex and Zoom.

LAW no. 1 of January 5, 2011, published in the Official Gazette no. 18/ January 10, 2011, Law that abrogated the Education Law number 84/1995 and Law number 128/1997- on the Charter of the didactic staff, provides in Art. 70, paragraph (3) The educational establishments use the school platform of learning in order to provide support to students during or outside school hours, or for those who, for health reasons, are temporarily unable to attend school; paragraph (4) The establishment, management and permanent enrichment of the Virtual School Library and of the School e-learning Platform is the responsibility of the Ministry of Education, Research, Youth and Sports.

It is amended and supplemented by several laws and ordinances, including Law 126/2020 to supplement the National Education Law no. 1/2011. It introduces a new paragraph in Article 70 after paragraph 2 which shall read as follows "The Ministry of Education and Research provides students and teachers the necessary infrastructure, consisting of devices and Internet access, in order to access the Virtual School Library and the e-learning platform."

In Article 94 (2), a new section z) is inserted after section (y), which shall read as follows: "z) provides to each teacher and to each student who is entitled to the social support scholarship a laptop or tablet device, connected to the Internet, in order to be able to participate in the e-learning activities carried out outside classes."

This draft law was adopted by the Chamber of Deputies in the meeting of May 20, 2020, in compliance with the provisions of art. 76 para. (1) of the Romanian Constitution, republished, promulgated by decree 363/2020 on July 3, 2020.

The explanatory memorandum mentions the disadvantage of the lack of digital facilities that result in the increase of the risk of dropping out of school, Romania being a state with a high level of risk of poverty and social exclusion, over a third of Romanian children being exposed to this risk - 38.1\%. It differs in large cities $18.6 \%, 24.9 \%$ in small cities and $45.5 \%$ in rural areas.

The structural funds that can be accessed through the human capital operational programme 2014-2020, axis 6- Education and competence and other European Union programs in the future financial framework 2021-2027 represent a solution for the endowment and digitization of schools.

The didactic activity through technology and the internet is a form of organization of the didactic process that involves the replacement of the teaching-learning-evaluation hours, which presuppose the physical presence of the preschoolers/students in the classroom, with individual study activities and didactic activities in the online system, defined in the Order for the approval of the framework methodology on carrying out teaching activities through technology and the Internet as well as for the processing of personal data published in the Official Gazette number 837 of September 11, 2020. This activity, although clearly stipulated, becomes effective but equally depersonalized by the absence of direct contact, 
cancelling certain components of the teaching act and consequently teachers find themselves in the situation of reinventing themselves in terms of methods, and also in the situation where students perceive the educational act as changed, a change that can distort the attitude towards education, and the actual performances of the students will be able to confirm or refute this statement.

The process of digitalization of education in Romania began with the implementation of projects such as CRED- Relevant Curriculum for Open Education for All, which started in May 2018 amounting to 42 million euro and with a duration of 4 years. It is meant to train, with the help of 900 trainers, a number of 55,000 teachers - 40,000 primary school teachers and 15,000 middle school teachers, in the use of attractive and adapted methods and contents. The project also includes the development of open educational resources (RED) for all levels and methodological guides covering the subjects.

Another project, implemented by the Administration Agency of the National Informatics Network for Education and Research, through the Operational Programme Competitiveness 2014-2020, carried out from September 2019 to September 2021, is the project which aims to create a digital platform with open educational resources, of an Edulib virtual library, in order to create a centralized integrated environment able to meet the needs of the use of educational resources in the modern educational process. The expected results are the creation of a digital platform with open educational resources, the endowment of 5,400 middle schools with multimedia kits and the training of 5,400 teachers.

The National Council of Students also proposed the project "Digitalization of Education - long-term solution", asking the Romanian Government to take directions of action in order to ensure the digitalization of education in a participatory, transparent, equitable manner, which represents a priority for the educational system. They also mention the position of the Lifelong Learning Platform on the importance of digitalization in education, a priority at European level, the National Strategy in the field of lifelong learning in Romania does not have monitoring indicators and is not reflected on the public agenda.

A U-report survey conducted by Unicef Romania regarding the online school tells us that a third of Romanian students are not satisfied with the online school and do not attend courses through virtual platforms. The most popular platforms used for online communication are Zoom (25\%) and Google Class (23\%), but also Whatssapp (20\%). Other platforms used include Messenger (13\%), Skype (3\%) and Discord (2\%). Another 218 children and young people mentioned other platforms and according to their answers, $33.98 \%$ have access to education during this period through the Adservio platform, $24.76 \%$ through Microsoft Teams, 7.77\% - Google Services, such as Google Drive and Google Classroom, $5.34 \%$ - the platform of the school where they study, 3.40\% -Webex, and less than $2 \%$ through the platforms Meet, 24edu, Sociology and WhatsApp. $18.45 \%$ of these respondents keep in touch with teachers through other platforms, namely Facebook and Facebook Messenger. Regarding the way students have adapted on these platforms, $82 \%$ have adapted easily or a little difficult, while $8 \%$ consider that it is difficult for them to adapt.

Between December 18, 2020 and February 15, 2021, the Strategy on the Digitization of Education in Romania is in public consultation.

The order on amending and supplementing the annex to the order of the Minister of Education and Research no. 5545/2020 on the approval of the Framework Methodology on the development of teaching activities through technology and the Internet as well as for the processing of personal data provides for the design of activities in both synchronous and 
asynchronous system and the obligation to participate in these activities (introduced by art.14 letter f.)

One of the biggest challenges was equal access to quality remote learning, as some teachers, trainers, students did not have digital skills or access to technology or the Internet, especially those from disadvantaged backgrounds, in rural areas, but and those with special educational needs, with a higher risk of early school dropout for those exposed from a socioeconomic point of view. These institutions are more than places where people learn and train, as they also offer a sense of community, of socialization, and their lack can lead to anxiety, social isolation and stress.

Both teachers and trainers have adapted to remote teaching changing from face-toface teaching, but as many lacked the necessary experience, knowledge, skills, aptitudes, a specific training was needed and an increase in workload occurred during this period. According to the OECD TALIS study (2018), less than $40 \%$ of teachers felt well prepared for the use of ICT in the teaching process.

The Council of Europe states in "Council conclusions on combating the crisis caused by the COVID-19 pandemic in education and training" the fact that trainers and teachers showed admirable dedication and creativity, an openness to collaboration, co-creation and mutual learning, even affecting the balance between their personal and professional lives. Adult learners, especially the low-skilled ones, do not have the digital skills needed to participate in digital learning, which diminishes their opportunities for improvement and retraining".

The pandemic has affected international and European learning mobility, with crossborder learning mobility programmes initially suspended or postponed, with many Erasmus + activities also moving to the virtual environment.

During this period, many quality educational materials and practices have been developed, virtual learning environments that facilitate the use of existing online learning platforms have been supported, new ones, but also team collaboration tools have been developed, television broadcasts have been used to provide educational content, professional development opportunities were provided for teachers and trainers, equipment for those from socio-economically disadvantaged areas or environments and printed educational materials were distributed in some cases, the access to digital content in libraries was facilitated and psychological support for those in need was provided.

The Council of Europe calls on the Commission, in accordance with its competences and with due regard for the principle of subsidiarity, to work closely with international organizations such as the Council of Europe, UNESCO and the OECD on the provision and dissemination of information on the implications of the COVID-19 pandemic on education and training.

\section{CONCLUSION}

These challenges also provided a valuable learning experience, accelerating the digital transformation of education and training institutions. The impact of the pandemic on education and training demonstrates the need for continuing the process of transformation and development of digital skills and competences of both teachers, trainers and students, continuing the exchange of information on experience and best practice, the examination of innovation opportunities to accelerate digital transformation of education and training institutions and reduce the digital sideslip. 
I believe that, in order to strengthen resilience and prepare for future effective and appropriate emergency responses timely, the possibility of integrating high-quality digital learning as part of the educational offer at all levels, into all types of education and training must be examined, with digital tools adapted to the ages and needs of learners and respecting the rules of data protection, privacy, cybersecurity and security, ensuring equal opportunities and continuous access to education and training for all ages, validating and recognizing learning outcomes acquired and supporting the development of digital infrastructure, digital skills and competences, through funding from the European Union and Digital Europe Programmes and strengthening the development of European and national public policies.

In creating the European Education Area, together with the Strategic Framework for European Cooperation in the field of Post-2020 Education and Training, the new Digital Education Action Plan and the updated Competence Agenda, the lessons learned from the crisis caused by the COVID-19 pandemic must be taken into account, regarding the digital transformation of education and training systems, paying particular attention to quality and societal challenges such as ensuring inclusion and equal opportunities, promoting cohesion and combating misinformation.

Further efforts should be made to facilitate exchanges regarding the challenges and measures taken by Member States, including by connecting and improving the availability of databases containing open educational resources and the access thereof, in order to facilitate the exchange of different remote learning methodologies, tools and materials. In this context, to capitalize on existing opportunities, such as those available through eTwinning, the School Education Gateway platform and the e-Platform for Adult Learning in Europe (EPALE), to promote the use of self-assessment tools such as SELFIE and HEInnovate to support the capacity and digital transformation of schools and higher education institutions. 


\section{BIBLIOGRAFY:}

[1] Law of National Education no.1/ 2011, published in Monitor no 18/ 10 January, 2011 http://www.cdep.ro/pls/legis/legis_pck.htp_act?ida=101120

[2] Digital Education Strategy https://www.edu.ro/sites/default/files/SMART.Edu\%20$\% 20$ document $\% 20$ consultare.pdf

[3] https://www.unicef.org/romania/sites/unicef.org.romania/files/202007/ECAR\%20CONSIDERATIONS\%20FOR\%20EDUCATION\%20PROVISION\%20Romanian.pdf

[4] https://edtechmagazine.com/higher/article/2020/05/emergency-remote-teaching-rigorous-online-learningperfcon

[5] https://er.educause.edu/articles/2020/3/the-difference-between-emergency-remote-teaching-and-onlinelearning

[6] https://www.roedu.net/News/View/95d06643-3145-4fb9-ad53-caffa2e79d03

[7] https://www.roedu.net/Projects/View/86d415fb-aeaa-4047-81ce-189c3eb18dd8

[8] . https://consiliulelevilor.ro/wp-content/uploads/2020/03/Digitalizarea-educa\%C8\%9Biei-policy-paper.pdf

[9] https://eacea.ec.europa.eu/national-policies/eurydice/content/lifelong-learning-strategy-64_ro

[10] https://www.unicef.org/romania/ro/pove\%C8\%99ti/sondaj-u-report-privind-\%C $8 \% 99$ coala-online

[11] http://lllplatform.eu/policy-areas/participatory-democracy/

[12] Strategia Națională de Învățare pe tot Parcursul Vieții 2015-202 https://eacea.ec.europa.eu/nationalpolicies/eurydice/content/lifelong-learning-strategy-64_ro

[13] https://images.capital.ro/wp-content/uploads/2020/12/OMEC-6200_Modificare-Metodologie-online_1.pdf

[14] http://legislatie.just.ro/Public/DetaliiDocumentAfis/229929

[15] https://data.consilium.europa.eu/doc/document/ST-8610-2020-INIT/ro/pdf

[16] https://digital.educred.ro/

[17] https://eduonline.roedu.net/ 